\title{
Efficiency of castor oil-based polyurethane in the production of plywood panels
}

\section{Eficiência do poliuretano à base de óleo de mamona na produção de painéis compensados}

\author{
Luana Wilczak ${ }^{1}$, Rosilani Trianoski ${ }^{2}$, Salvador Claro Neto ${ }^{3}$, \\ Caroline Rodrigues Pereira de Paula ${ }^{1 *}$, Rodrigo Lupinacci Villanova ${ }^{1}$ and \\ Elaine Azevedo ${ }^{1}$
}

\begin{abstract}
Plywood panels are produced with polymeric adhesives derived from petroleum that can be hazardous to health and the environment, since they are made from non-renewable sources and contain organic solvents in their composition, which can cause diseases such as cancer. Polyurethane adhesives derived from castor oil-based are an alternative to those materials, because it is biodegradable and non-hazardous. The aim of this work was to evaluate the mechanical properties of plywood panels made with polyurethane adhesive derived from castor oil-based. Panels were produced with five sheets of Pinus caribaea bahamensis wood and three different adhesives: urea-formaldehyde, phenol formaldehyde, and polyurethane with a glue spread line of $180 \mathrm{~g} / \mathrm{m}^{2}$ for phenolic adhesives, and $120,140,160,180 \mathrm{~g} / \mathrm{m}^{2}$ for polyurethane. The panels were evaluated in terms of specific mass, shear strength before and after immersion on boiling and cold water, in cycle and without immersion, and bending strength parallel and perpendicular to the fibers orientation. Results were statistically analyzed. The plywood panels produced with polyurethane adhesive derived from castor oil have superior shear strength and bending strength similar than those produced with the others tested adhesives, and the weight of $120 \mathrm{~g} / \mathrm{m}^{2}$ is the most suitable for bonding.
\end{abstract}

Keywords: plywood; biodegradable polyurethane; mechanical properties

\section{Resumo}

Os painéis compensados são produzidos com adesivos poliméricos derivados do petróleo que podem ser prejudiciais à saúde e ao meio ambiente, pois são provenientes de fontes não renováveis e contêm solventes orgânicos em sua composição, que podem causar doenças como o câncer. Adesivos de poliuretano derivados de óleo de mamona são uma alternativa a esses materiais, pois são biodegradáveis e não prejudiciais. $\mathrm{O}$ objetivo deste trabalho foi avaliar as propriedades mecânicas de painéis de compensados feitos com adesivos derivados de poliuretano à base de óleo de mamona. Os painéis foram produzidos com cinco folhas de madeira de Pinus caribaea bahamensis e três diferentes adesivos: uréia-formaldeído, fenol-formaldeído e poliuretano com gramatura de linha de cola de $180 \mathrm{~g} / \mathrm{m} 2$ para adesivos fenólicos, e $120,140,160,180 \mathrm{~g} / \mathrm{m}^{2}$ para poliuretano. Os painéis foram avaliados em termos de peso específico, resistência ao cisalhamento após imersão em água fervente e fria, em ciclo e sem imersão, e resistência à flexão paralela e perpendicular à orientação das fibras. Os resultados foram analisados estatisticamente. Os painéis produzidos com adesivo de poliuretano derivado de óleo de mamona apresentam resistência ao cisalhamento superior e resistência à flexão semelhante aos produzidos com os demais adesivos testados, sendo a gramatura de $120 \mathrm{~g} / \mathrm{m}^{2}$ a mais indicada para a colagem.

Palavras-chave: painel laminado; poliuretano biodegradavel; propriedades mecânicas

1. Universidade Tecnológica Federal do Paraná - UTFPR. Curitiba / PR, Brazil.

2. Universidade Federal do Paraná - UFPR. Curitiba / PR, Brazil.

3. Instituto de Química de São Carlos, Universidade de São Paulo - USP. São Carlos / SP, Brazil.

* Corresponding author: carolrodrigues.floresta@gmail.com

Sci. For., Piracicaba, v. 47, n. 123, p. 463-471, set. 2019

DOI: doi.org/10.18671/scifor.v47n123.08 
Wilczak et al. - Efficiency of castor oil-based polyurethane in the production

of plywood panels

\section{INTRODUCTION}

Wood has a set of unique properties when employed as a construction material, such as strength, flexibility, fire resistance, durability, and insulation (IWAKIRI, 2005). Natural wood has an anisotropic and heterogeneous structure, so the main directions of strain are not necessarily those of stress (NGARGUEUDEDJIM; ANNOUAR, 2015)

In order to overcome this limitations, wood panels are produced worldwide, and such as panels that can be plywood, MDF, agglomerated, structural wood, OSB, and laminated wood products (KABOORANI et al., 2012).

Plywood panels are made with wood sheets glued in such a way that the fibers of the individual sheets are arranged perpendicularly to each other. Such arrangement increases the isotropy of the wood, giving the material high dimensional stability and uniform mechanical strength (IWAKIRI, 2005).

The production of plywood panels was boosted by the development of synthetic resins, such as urea-based resins and phenolic resins (IWAKIRI, 2005; SILVA, 2015). These resins are produced with formaldehyde solvent, and it can release this compound for months or years, even though the panels are coated with different materials (BREGINSKI, 2015; SALTHAMMER, 2010).

Inhalation of formaldehyde can cause dizziness, headaches, nausea, vomit, lacrimation, and dryness of the airways (IARC, 2004; HAUPTMANN et al., 2004; IARC, 2015). In July 2004, the International Agency for Research on Cancer - intergovernmental agency which is part of the United Nations Organization -changed the classification of formaldehyde from group 2, probably carcinogenic to humans, to group 1, carcinogenic to humans (IARC, 2004; SOLAL et al., 2008).

In this context, the use of adhesives derived from vegetal oils has advantages, such as the reduction in the production of residues that aren't easily degradable, and the elimination of hazards due to inhalation of formaldehyde (AZEVEDO, 2009).

The use of adhesive polyurethane derived from castor oil was considered adequate for adhesion for Edge Glued Panel with Pinus taeda and too adhesion for MDF in furniture production (MOLLEKEN et al., 2016; PEREIRA et al., 2016).

The aim of this work was to evaluate the physical and mechanical properties of plywood panels made withpolyurethane adhesives derived from castor oil and to compare the results obtained with other adhesives.

\section{MATERIALS AND METHODS}

Sheets of Pinus caribaea bahamensis were taken from a 17 years old tree, planted in Itararé-SP, with

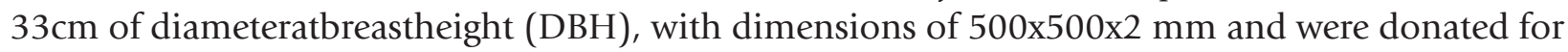
Valor Florestal Industry. These sheets were oven dried during 24 hours at $100{ }^{\circ} \mathrm{C} \pm 2{ }^{\circ} \mathrm{C}$ until the humidity was lowered to $6 \%$ to $8 \%$ by weight. The employed adhesives were the castor oil-based polyurethane (PU) with solid content of $100 \%$, density of $1,074 \mathrm{~g} / \mathrm{cm}^{3}, \mathrm{pH} 5,5$; Urea formaldehyde (UF) with solid content of $66 \%$, viscosity of $300 \mathrm{cP}, \mathrm{pH}=7,6$, densityof $1,28 \mathrm{~g} / \mathrm{cm}^{3}$ and gel time of 60s; Fenol-formaldehyde (PF) with solid content of 51,57\%, viscosity of 503cP, $\mathrm{pH}=12,66$, densityof $1,22 \mathrm{~g} / \mathrm{cm}^{3}$ and gel time of 7 minutes (ROSA, 2015); the PU was donated for Cequil Industria e Comércio de Adesivos de Araraquara, the UF and FF was donated for Hexion.

The process were divided in two stages: Stage 1 - Production and comparison of plywood with UF, PF and PU adhesive with glue grammage line of $180 \mathrm{~g} / \mathrm{m}^{2}$; Stage 2 - Production and comparison of plywood with PU adhesive with glue grammage line of 180,160, 140 and $120 \mathrm{~g} / \mathrm{m}^{2}$. All the panels were produced with five wood sheets arranged perpendicular to each other. The parameters used to produce the panels are shown in Table 1.

In total, three panels for each condition described in Table 1 were produced. The samples were cut for the shear strength test, three-point bending test and placed in a climatic chamber at $20 \pm 3{ }^{\circ} \mathrm{C}$ and relative humidity of $65 \pm 5^{\circ} \mathrm{C}$.

The specific mass analyses were made according to the NBR 9485 (ABNT, 2011). Shear tests were made after immersion in both cold and hot water, in cycles, and without immersion, according to the EN 314:1996 Standard (EUROPEAN STANDARD, 1996). Three-point bending tests of specimens in parallel and perpendicular directions regarding the fibers alignment were also conducted, according 
Table 1 - Parameters used to produce the plywood panels

Tabela 1 - Parâmetros utilizados na produção dos painéis compensados

\begin{tabular}{cccccc}
\hline Stage & Adhesive & $\begin{array}{c}\text { Temperature } \\
\left({ }^{\circ} \mathbf{C}\right)\end{array}$ & $\begin{array}{c}\text { Weight } \\
\left(\mathbf{g} / \mathbf{m}^{\mathbf{2}}\right)\end{array}$ & Time (min) & $\begin{array}{c}\text { Pressure } \\
(\mathbf{M P a})\end{array}$ \\
\hline 1 & Urea-formaldehyde & 110 & 180 & 8 & 1 \\
1 & Phenol formaldehyde & 130 & 180 & 10 & 1 \\
1 & Castor oil-basedpolyuretahane & 90 & 180 & 20 & 1 \\
2 & Castor oil-basedpolyuretahane & 90 & 160 & 20 & 2 \\
2 & Castor oil-basedpolyuretahane & 90 & 140 & 20 & 2 \\
2 & Castor oil-basedpolyuretahane & 90 & 120 & 20 & 2 \\
\hline
\end{tabular}

to the EN 310:1993 Standard (EUROPEAN STARDAD, 1993). Shear and bending tests were carried out in a universal testing machine EMIC DL 2000.

The results were calculated in statistical program Statgraphics Centurion 16.1.11. The data were submitted to Grubb's test to assess the occurrence of outliers, Kolmogorov'stest to test the adherence of data, Bartlett's test for homogeneity of variance and analysis of variance. When rejected the null hypothesis, was applied Tukey HDS with 95\% probability.

\section{RESULTS}

\section{Stage 1 \\ Specific mass}

The specific mass of the plywood panels with different adhesives are shown in Fig. 1.

The specific mass of all panels were statistically equivalent according to the Tukey's HDS test, ranging from 541 to $565 \mathrm{~kg} / \mathrm{m}^{3}$ in Stage 1, Fig. 1. The specific mass of Pinus caribaea hondurensis with $12 \%$ humidity, as reported by Rezende et al. (2008), varied from $510 \mathrm{~kg} / \mathrm{m}^{3}$ to $560 \mathrm{~kg} / \mathrm{m}^{3}$, showing that the specific mass of the plywood panels was slightly affected by the adhesives. The process of pressurizing the wooden sheets results in a volume reduction of the material, however, the mass of the panel remains constant, hence increasing the plywood's specific mass.

Almeida et al.(2012) in a study on plywood produced with Pinus sp. hybrids with double-glue phenol-formaldehyde adhesive with a glue-line weight of $380 \mathrm{~g} / \mathrm{m}^{2}$, had a specific mass of $413 \mathrm{~kg} / \mathrm{m}^{3}$, a value below that found in this study.

Ayrilmis and Ozbay (2017) produced plywood panels of Pinus sylvestre is with fenol-formaldehyde resin, modified with $20 \%$ of a bio-oil with a glue-line grammage of $220 \mathrm{~g} / \mathrm{m}^{2}$,obtaining a specific mass of $770 \mathrm{~kg} / \mathrm{m}^{3}$.

Ozturk et al. (2016) produced plywood panels of Pinus sylvestris with a polyethilene adhesive; when utilizing a glue-line grammage of $160 \mathrm{~g} / \mathrm{m}^{2}$ the resultant density was of $530 \mathrm{~kg} / \mathrm{m}^{3}$, which is statistically similar to the one obtained with a glue-line weight of $240 \mathrm{~g} / \mathrm{m}^{2}, 528 \mathrm{~kg} / \mathrm{m}^{3}$.

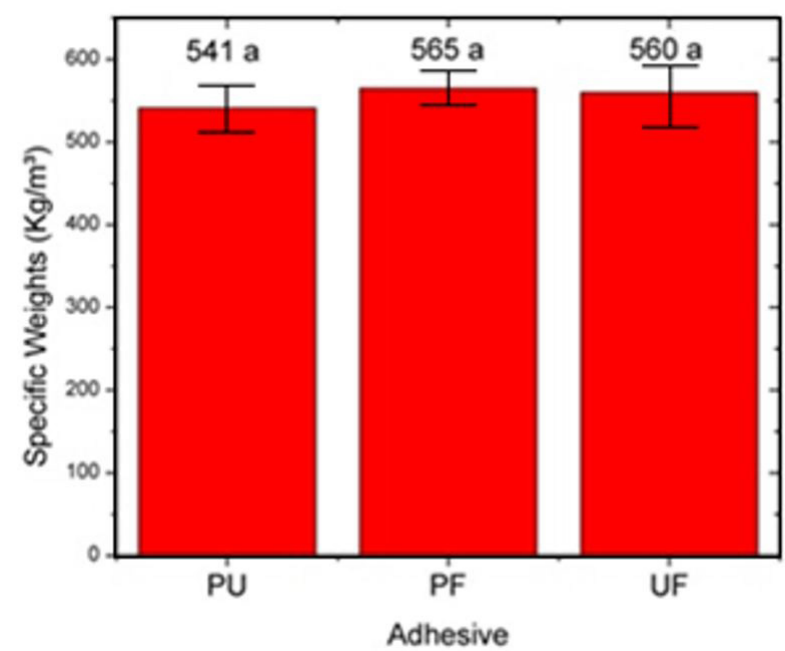

Figure 1 - Specific weight of the plywood panels with humidity $12 \%$ at Stage 1

Figura 1 - Massa específica dos painéis compensados com $12 \%$ de umidade da Etapa 1 
Wilczak et al. - Efficiency of castor oil-based polyurethane in the production

of plywood panels

\section{Shear strength}

The shear strength of the plywood panels for different conditions are shown in Table 2.

From the data shown in Table 2, it is possible to observe that plywood panels produced with adhesive derived from castor oil-based polyurethane had the highest shear strength for all treatments, and these panels attends the requirements of the EN 314 Standard (EUROPEAN STANDARD, 1996), which is a minimum strength of $1 \mathrm{MPa}$.

For panels with shear strength between 0.2 and $0.4 \mathrm{MPa}$, the EN 314 standard establishes that the failure in the wood should be higher than $80 \%$, when the resistance is between 0.4 and $0.6 \mathrm{MPa}$, the fault must be higher to $60 \%$, in case of resistance between 0.6 and $0.8 \mathrm{MPa}$ the failure must be greater than $40 \%$, and in panels whose shear strength is higher than $1 \mathrm{MPa}$ there is no requirement for failure in the wood.

Failure percentage refers to the amount of wood remaining in the fracture area. A high percentage indicates that the rupture occurred in the wood, not in the contact point between the wood and the adhesive, indicating that the strength of the adhesive is higher than the wood strength.

For dry and cold water conditions, PU plywood panels showed a higher failure percentage than the other ones, as can be seen in Table 2. For boiling and cycle conditions, such percentage was lower than compared to the panels made with phenol formaldehyde adhesive. The chemical bonding between the isoscianide, present in the polyurethane, and free hydroxils of the wood promote an increased adhesion between the composite's components when compared to phenolic adhesives.However, when submitted to cycle and boiling conditions, in which specimens are submerged in water at $100^{\circ} \mathrm{C}$, the polyurethane's stiffness and adhesion diminish, since it's glass transition temperature (Tg) is of about $60^{\circ} \mathrm{C}$ (AZEVEDO, 2009). This also reduces the percentage of specimens that presented failure in the wood when compared to the fenol-formaldehyde adhesive.

Table 2 - Shear strength (RGL - Resistance of the Glue Line) and failure percentage for the wood panels with different adhesives $\left(180 \mathrm{~g} / \mathrm{m}^{2}\right)$

Tabela 2 - Cisalhamento (RLC - Resistência da Linha de Cola) e porcentagem de falha na madeira para painéis com diferentes adesivos $\left(180 \mathrm{~g} / \mathrm{m}^{2}\right)$

\begin{tabular}{lcccc}
\hline \multicolumn{2}{c}{ Treatments } & PU & PF & UF \\
\hline Dry & RGL (MPa) & $2.71 \mathrm{a}(11.71 \%)$ & $2.26 \mathrm{~b}(10.43 \%)$ & $1.65 \mathrm{c}(12.64 \%)$ \\
\multirow{3}{*}{ Cold water } & Failure (\%) & 76.33 & 40.33 & 21.33 \\
& RGL (MPa) & $1.99 \mathrm{a}(16.03 \%)$ & $0.91 \mathrm{c}(24.73 \%)$ & $1.17 \mathrm{~b}(20.76 \%)$ \\
Cycle & Falha (\%) & 10.67 & 6.67 & 8.33 \\
& RGL (MPa) & $1.11 \mathrm{a}(21.28 \%)$ & $0.79 \mathrm{~b}(18.52 \%)$ & - \\
Boiling & Falha (\%) & 2.50 & 5.67 & - \\
& RGL (MPa) & $1.09 \mathrm{a}(51.67 \%)$ & $0.88 \mathrm{a}(16.16 \%)$ & - \\
\hline
\end{tabular}

*Values followed by equal letters in the same column are considered the same according to the Tukey's HDS test for $95 \%$ confidence. ** Values in parenthesis are the variation coefficients.

For plywood panels of Pinus caribaea wood produced with urea-formaldehyde adhesive in weight $350 \mathrm{~g} / \mathrm{m}^{2}$, Iwakiri et al. (2001) reported values of shear strength of $1.28 \mathrm{MPa}$ and $0.75 \mathrm{MPa}$ for dry and cold water treatments, respectively. Shear strenght values for phenol formaldehyde adhesives reported in the same work were $2.34 \mathrm{MPa}$ and $1.45 \mathrm{MPa}$ for dry and boiling treatments, respectively. Such values are very close to those obtained it the present work.

Mendes et al (2013) produced panels with Pinus taeda slides and phenol-formaldehyde adhesive in grammage $420 \mathrm{~g} / \mathrm{m}^{2}$ distributed in double line and obtained resistance of the glue line in dry treatment of 2.9 MPa, and after boiling 1.63 MPa.

\section{Three-point bending test}

The results obtained in the three-point bending test are shown in Table 3.

The Modulus of Rupture (MOR) and the Modulus of Elasticity (MOE) in bending strength of the panels, with samples cut in parallel orientation to the fibers of the wood sheet upper layer are statistically equal for all tested adhesives. For thesamples cut in perpendicular orientation, the results for phenol formaldehyde and polyurethane are similar, but panels made with urea-formaldehyde adhesives had lower strength. 
Table 3 - Flexural strength (MOR), and elastic modulus (MOE) for the wood panels with different adhesives $\left(180 \mathrm{~g} / \mathrm{m}^{2}\right)$ Tabela 3 - Resistência à flexão (MOR) e módulo elástico (MOE) para painéis com diferentes adesivos $\left(180 \mathrm{~g} / \mathrm{m}^{2}\right)$

\begin{tabular}{llrrr}
\hline \multirow{2}{*}{ Orientation } & \multirow{2}{*}{ Property } & \multicolumn{2}{c}{ Adhesive used in the production of the panels } \\
\cline { 3 - 5 } & & PU & PF & UF \\
\hline Parallel & MOR (MPa) & $63.32(16.80 \%) \mathrm{a}$ & $61.19(20.84 \%) \mathrm{a}$ & $61.98(12.98 \%) \mathrm{a}$ \\
\multirow{3}{*}{ Perpendicular } & MOE (GPa) & $6.61(17.35 \%) \mathrm{a}$ & $7.19(27.87 \%) \mathrm{a}$ & $7.15(21.22 \%) \mathrm{a}$ \\
& MOR (MPa) & $34.78(14.22 \%) \mathrm{a}$ & $32.18(18.39 \%) \mathrm{a}$ & $25.22(14.98 \%) \mathrm{b}$ \\
& MOE (GPa) & $2.13(13.13 \%) \mathrm{ab}$ & $2.25(19.75 \%) \mathrm{a}$ & $1.92(13.18 \%) \mathrm{b}$ \\
\hline
\end{tabular}

* Values followed by equal letters in the same line are considered the same according to the Tukey's HDS test for $95 \%$ confidence. ** Values in parenthesis are the variation coefficients.

Plywood panels with higher values of density tend to present higher modulus of rupture and modulus of elasticity (TRIANOSKI; IWAKIRI, 2018). In addition to the direct relationship between the density of the plywood and the density of the wood used in its composition, other factors such as the chemical and anatomical properties of the wood of different species may influence the mechanical properties of the panels.

In a study of Eucalyptus grandis with adhesive derived from castor oil-based polyurethane with adhesive grammage of $250 \mathrm{~g} / \mathrm{m}^{2}$, Dias and Lahr (2004) obtained in parallel orientation the fibers $87 \mathrm{MPa}$ of resistance to rupture and $11.11 \mathrm{GPa}$ of modulus of elasticity, in analysis perpendicular to the fibers the resistance to rupture was of $61 \mathrm{MPa}$, and modulus of elasticity of $6.24 \mathrm{GPa}$.

Trianoski and Iwakiri (2018) studied plywood panels produced with sheets of Pinus taeda with 18 years and adhesive Urea Formaldehyde with adhesive grammage of $180 \mathrm{~g} / \mathrm{m}^{2}$ and obtained, in parallel orientation to the fibers, rupture strength of 47.89 MPa and modulus of elasticity of 3.99 GPa; when the fibers were perpendicularly analyzed, the tensile strength was $34.11 \mathrm{MPa}$ and the modulus of elasticity was $1.87 \mathrm{Gpa}$.

Campos et al. (2009) analyzed plywood of Pinus sp. with polyurethane adhesive and adhesive grammage of $400 \mathrm{~g} / \mathrm{m}^{2}$ and double glue line, obtained in parallel orientation the fibers resistance to rupture of $44 \mathrm{MPa}$ and modulus of elasticity of $13 \mathrm{GPa}$

The variations may occur depending on the kind of the wood, its grammage, type of adhesive, as well as the environment conditions during the production of the plywood panels.

\section{Stage 2}

\section{Specific mass}

The specific mass of the plywood panels with different glue grammage line are shown in Fig. 2

In figure 2 it can be seen that there was no statistical difference with respect to the apparent density of the panels at humidity of $12 \%$, that is, the slides chosen to compose the panels have the same characteristic, eliminating the influence of the specific mass in the quality of the panels and the interference of this factor in the static flexural strength of the composites.

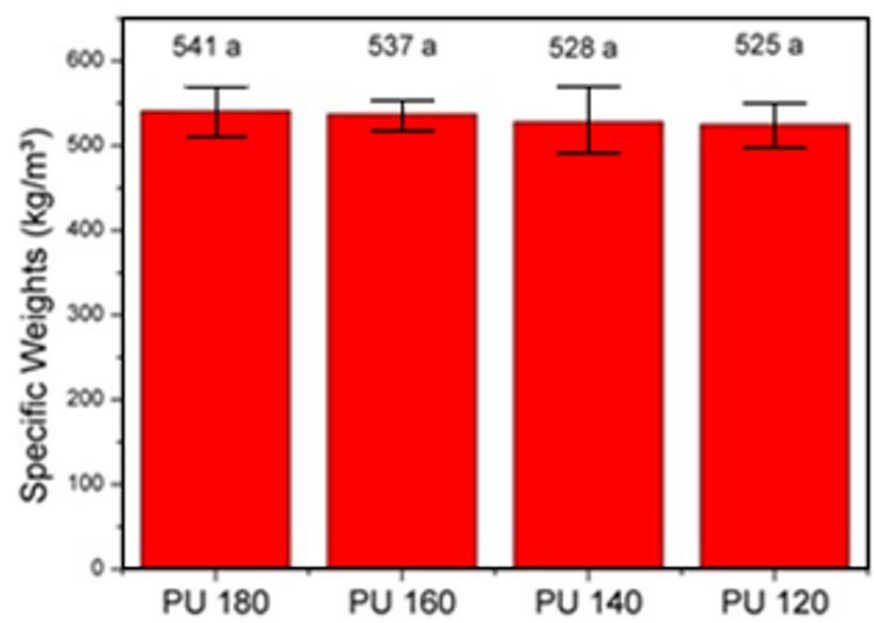

Figure 2 - Specific weight of the plywood panels with humidity $12 \%$ at Stage 2

Figura 2 - Massa específica dos painéis compensados com 12\% de umidade da Etapa 2 
Wilczak et al. - Efficiency of castor oil-based polyurethane in the production

of plywood panels

A higher density of the wood may influence the formation of the adhesive bond between the blades, because of the greater difficulty of penetration of the adhesive, in addition to generating greater internal pressure of steam during the hot pressing. This contributes to the reduction of the polymerization rate of the resin (IWAKIRI et. al., 2007).

In an ABIMCI (2007) report on the analysis of panels of Pinus sp. and phenolic adhesive for trade, intended for external use in structural application, has a specific average mass of panels of $552 \mathrm{~kg} / \mathrm{m}^{3}$, which is very close to that obtained in this work.

\section{Shear strength}

The shear strength of the plywood panels for different conditions are shown in Table 4.

Table 4 - Shear strength (RGL - Resistance of the Glue Line) and failure percentage for the wood panels with PU with glue spread line of $180,160,140$ and $120 \mathrm{~g} / \mathrm{m}^{2}$

Tabela 4 - Cisalhamento (RLC - Resistência da Linha de Cola) e porcentagem de falha na madeira para painéis com PU e gramatura de linha de cola de $180,160,140$ e $120 \mathrm{~g} / \mathrm{m}^{2}$

\begin{tabular}{|c|c|c|c|c|c|}
\hline \multicolumn{2}{|c|}{ Treatments } & \multirow{2}{*}{$\frac{\text { PU } 180}{2.71 \text { a }(11.71 \%)}$} & \multirow{2}{*}{$\frac{\text { PU } 160}{2.70 \text { a }(10.16 \%)}$} & \multirow{2}{*}{$\frac{\text { PU } 140}{2.38 \mathrm{~b}(14.32 \%)}$} & \multirow{2}{*}{$\frac{\text { PU } 120}{2.62 \text { a }(7.52 \%)}$} \\
\hline Dry & RGL (MPa) & & & & \\
\hline & Failure (\%) & 76.33 & 86.00 & 94.33 & 84.67 \\
\hline \multirow[t]{2}{*}{ Cold water } & $\mathrm{RGL}(\mathrm{MPa})$ & 1.99 a $(16.03 \%)$ & 1.97 a $(10.52 \%)$ & 1.75 a $(10.12 \%)$ & $1.81 \mathrm{a}(14.64 \%)$ \\
\hline & Falha (\%) & 10.67 & 8.67 & 23.33 & 11.79 \\
\hline \multirow[t]{2}{*}{ Cycle } & RGL (MPa) & 1.11 a $(21.28 \%)$ & 1.44 a $(18.04 \%)$ & $1.42 \mathrm{ab}(10.99 \%)$ & 1.09 b (52.36\%) \\
\hline & Falha (\%) & 2.50 & 7.33 & 26.0 & 10,71 \\
\hline \multirow[t]{2}{*}{ Boiling } & RGL (MPa) & 1.09 a $(51.67 \%)$ & 1.44 a $(11.62 \%)$ & 1.32 a $(11.68 \%)$ & 1.14 a $(45.73 \%)$ \\
\hline & Falha (\%) & 5.38 & 6.53 & 11.33 & 10.67 \\
\hline
\end{tabular}

* Values followed by equal letters in the same line are considered the same according to the Tukey's HDS test for $95 \%$ confidence. *** Values in parenthesis are the variation coefficients.

Statistical differences were observed in the dry and boiling cycle treatments. All weights presented mean values of shear stresses above the minimum value of $1.0 \mathrm{MPa}$, in accordance with EN 314-2: 1996.

The plywood panels of the Eucalyptus grandis with adhesive castor oil-based polyurethane with adhesive grammage of $250 \mathrm{~g} / \mathrm{m}^{2}$ studied by Dias and Lahr (2004) show presented a shear stress of 3.1 $\mathrm{MPa}$ and $78 \%$ of failure in the wood in dry condition, $2.7 \mathrm{MPa}$ and $32 \%$ of failure in the wood when wet and $1.9 \mathrm{MPa}$ and $16 \%$ of failure in the wood after boiling.

Bianche et al (2016) analyzed panels produced with Pinus sheets and adhesive polyurethane derived from castor oil with adhesive grammage of 150 and $200 \mathrm{~g} / \mathrm{m}^{2}$. Considering glue line $150 \mathrm{~g} / \mathrm{m}^{2}$, in dry condition, the shear strength was $4.67 \mathrm{MPa}$ and the wood failure was $36 \%$; already in line of glue grammage of $200 \mathrm{~g} / \mathrm{m}^{2}$ the resistance to the shear was of $4.24 \mathrm{MPa}$ and the failure in the wood of $48 \%$. When submitted to the cold water condition they obtained for panels with $150 \mathrm{~g} / \mathrm{m}^{2}$ of adhesive shear strength of $2.76 \mathrm{MPa}$ and $10.9 \%$ of failure in the wood; in panels with a glue line grammage of $200 \mathrm{~g} / \mathrm{m}^{2}$ the shear strength was $3.12 \mathrm{MPa}$ and the wood failure was $20.3 \%$. In panels whose glue line was thicker, $250 \mathrm{~g} / \mathrm{m}^{2}$, the authors noticed a reduction in shear strength and failure of the wood in both conditions (BIANCHE et al, 2016)

The results obtained by Bianche et al (2016) and Dias and Lahr (2004) suggest that the higher weight of glue line, to an optimum point, allied to the characteristics of the wood used influence the shear strength, as well as the percentage of wood failure.

The average values obtained for panels glued with phenolic adhesive presented 1.25 $\mathrm{MPa}$ of resistance to the glue line for the treatment cycle; and 1.07 MPa for boiling treatment (ABIMCI, 2007).

Based on the requirements of the European standard,produced with the polyurethane adhesive derived from castor oil in the grammage of $180 \mathrm{~g} / \mathrm{m}^{2}, 160 \mathrm{~g} / \mathrm{m}^{2}, 140 \mathrm{~g} / \mathrm{m}^{2}, 120 \mathrm{~g} / \mathrm{m}^{2}$ under the conditions used for this work, may be indicated for internal and external use.

\section{Three-point bending test}

The mean static bending results for weights of $180 \mathrm{~g} / \mathrm{m}^{2}, 160 \mathrm{~g} / \mathrm{m}^{2}, 140 \mathrm{~g} / \mathrm{m}^{2}$ and $120 \mathrm{~g} / \mathrm{m}^{2}$ are shown in Table 5. 
Table 5 - Flexural strength (MOR) and elastic modulus (MOE) for the wood panels with polyurethane adhesive and glue spread line of 180,160, 140 and $120 \mathrm{~g} / \mathrm{m}^{2}$

Tabela 5 - Resistência à flexão (MOR) e módulo elástico (MOE) para painéis com adesivo poliuretano e gramatura de linha de cola de $180,160,140$ e $120 \mathrm{~g} / \mathrm{m}^{2}$

\begin{tabular}{llllll}
\hline \multirow{2}{*}{ Orientation } & \multirow{2}{*}{ Property } & \multicolumn{4}{c}{ Glue Line Weight for PU Adhesive } \\
\cline { 3 - 6 } & & \multicolumn{1}{c}{ PU 180 } & \multicolumn{1}{c}{ PU 160 } & \multicolumn{1}{c}{ PU 140 } & PU 120 \\
\hline Parallel & MOR (MPa) & $63.32 \mathrm{a}(16.80 \%)$ & $65.08 \mathrm{a}(18.38 \%)$ & $63.81 \mathrm{a}(11.49 \%)$ & $56.88 \mathrm{a}(23.07 \%)$ \\
\multirow{3}{*}{ Perpendicular } & MOE (GPa) & $6.61 \mathrm{ab}(17.35 \%)$ & $7.25 \mathrm{a}(20.88 \%)$ & $6.54 \mathrm{ab}(13,31)$ & $5.53 \mathrm{~b}(21.08 \%)$ \\
& MOR (MPa) & $34.78 \mathrm{a}(14.22 \%)$ & $27.29 \mathrm{~b}(7.76 \%)$ & $27.00 \mathrm{~b}(15.19 \%)$ & $31.07 \mathrm{ab}(9.59 \%)$ \\
& MOE (GPa) & $2.13 \mathrm{ab}(13.12 \%)$ & $1.98 \mathrm{a}(13.03 \%)$ & $2.09 \mathrm{a}(24.04 \%)$ & $2.12 \mathrm{a}(11.87 \%)$ \\
\hline
\end{tabular}

* Values followed by equal letters in the same line are considered the same according to the Tukey's HDS test for $95 \%$ confidence. ** Values in parenthesis are the variation coefficients.

Through the statistical analysis it can be seen that there were no variations of resistance parallel to the fibers between the different weights. This means that a plywood panel produced with the $180 \mathrm{~g} / \mathrm{m}^{2}$ polyurethane adhesive may have similar strength to the same panel produced at $120 \mathrm{~g} / \mathrm{m}^{2}$. From an economic point of view, this finding is of fundamental importance, since reducing the amount of adhesive in the panel making did not reduce the flexural strength values.

Campos et. al. (2009) obtained, for plywood panels of Pinus sp. with bicomponent polyurethane based on castor oil using a weight of $400 \mathrm{~g} / \mathrm{m}^{3}$, pressing at $1.5 \mathrm{MPa}$ at $60^{\circ} \mathrm{C}$ for 15 minutes, MOR ranging from 39 to $56 \mathrm{MPa}$ and $\mathrm{MOE}$ of 10 to $15.3 \mathrm{GPa}$ for static bending.

According to ABIMCI (2007) report, in relation to static bending, mean values for parallel and perpendicular to the grain rupture modules (MOR) were $45.36 \mathrm{MPa}$ and $32.05 \mathrm{MPa}$, respectively. The mean values for the parallel and perpendicular modulus of elasticity (MOE) were 5.1 GPa and 2.6 GPa, respectively.

It is possible to state that the polyurethane adhesive derived from castor oil can replace the phenol-formaldehyde based adhesive, which is a structural adhesive indicated for external use, when used in compensated panels.

The variations occurred in the analyzed results may be related to the scattering methodology employed and the quality of the wood used. In addition, for the weights of $180 \mathrm{~g} / \mathrm{m}^{2}$ and $160 \mathrm{~g} / \mathrm{m}^{2}$ the adhesive was run through the edges of the panel, which means that not all the adhesive applied was actually used in the panel gluing process, influencing in the results obtained in this work.

\section{CONCLUSIONS}

- The specific weight of the plywood panels was not affected by the type of adhesive employed in its production;

- The shear strength of plywood panels produced with adhesive made with castor oil-based polyurethane is higher than those produced with formaldehyde adhesives;

- The variation of the weight of the glue line did not affect the static flexural strength of the panels;

- When compared to plywood panels made with formaldehyde adhesives, there was no reduction in flexural strength of the plywood panels produced with the adhesive made with castor oil-based polyurethane;

- The production of plywood panels with Pinus caribaea bahamensis and adhesive made of castor oil-based polyurethane is technically viable;

- The most viable glue line weight for the production of these panels with polyurethane adhesive derived from castor oil is $120 \mathrm{~g} / \mathrm{m}^{2}$.

\section{REFERENCES}

ABIMCI - ASSOCIAÇÃO BRASILEIRA DA INDÚSTRIA DE MADEIRA PROCESSADA MECANICAMENTE. Compensados de Pinus. Curitiba: ABIMIC, 2007. 20 p.

ABNT - ASSOCIAÇÃO BRASILEIRA DAS NORMAS TÉCNICAS. NBR 9485: Chapas de Madeira compensada: Determinação da massa específica. Rio de Janeiro, 2011, 7 p. 
Wilczak et al. - Efficiency of castor oil-based polyurethane in the production of plywood panels

ALMEIDA, N. F.; JÚNIOR BORTOLETTO, G.; MEDES, R. F.; SURDI, P. G. Avaliação da madeira de Pinus elliotti var.Elliotti $x$ Pinus caribaea var. Hondurensis para a produção de compensados. Scientia Forestalis, Piracicaba, v. 40, n. 96, p. 435-443, 2012.

AYRILMIS, N.; ÖZBAY, G. Technological properties of plywood bonded with phenol-formaldehyde resol resin synthesised with bio-oil. Cerne, Lavras, v. 23, n. 4, p. 493-500, 2017.

AZEVEDO E. C. Efeito da radiação nas propriedades mecânicas do adesivo de poliuretana derivado de óleo de mamona. 153 p. 2009. Thesis (PhD in Dourado em Materials Engineering) - Universidade Federal do Paraná, Curitiba, 2009.

BIANCHE J. J. CARNEIRO A. C. O., LADEIRA J. P. S., TEIXEIRA A. P. M., PEREIRA F. A., OLIVEIRA B. S. Shear strength in the glue line of Eucalyptus sp. and Pinus sp. wood. Revista Árvore, Viçosa, v. 40, n. 6, p. 1109$1117,2016$.

BREGINSKI, H. D. B. Qualidade do ar: estudo sobre a presença de formaldeído. 136 p. 2015. Dissertation (Master in Construction) - Universidade Federal do Paraná, Curitiba, 2015.

CAMPOS, C. I.; MORAIS, R. D. V.; NASCIMENTO, M.F. Caracterização físico-mecânica de painéis de madeira compensada produzidos com Pinus sp. e resina poliuretana bi-componente. Revista Madeira, São Carlos, v. 10, n. 24, p. 37-50, 2009.

DIAS F. M.; LAHR, A. R. Alternative castor oil-based polyurethane adhesive used in the production of plywood. Materials Research, v. 7, n. 3, p. 413-420, 2004.

EN - EUROPEAN STANDARD. EN 314: Determination of shear strength.English version. Bruxelas, 1996.

EN - EUROPEAN STANDARD. EN 310: Determination of three point bending. English version, Bruxelas, 1993.

HAUPTMANN, M.; LUBIN, J. H.; STEWART, P. A.; HAYES, R. B.; BLAIR, A. Mortality from Solid Cancers among Workers in Formaldehyde Industries. American Journal of Epidemiology, v. 159, n. 2, p. 1117-1130, 2004.

IARC - INTERNATIONAL AGENCY FOR RESEARCH ON CANCER. Outdoor air pollution. IARC monographs on the evaluation of carcinogenic risks to humans, Lyon, v. 109 p. 35-134, 2015.

IARC - INTERNATIONAL AGENCY FOR RESEARCH ON CANCER. Formaldehyde, 2-Butoxyethanol and 1-tertButoxypropan-2-ol. IARC monographs on the evaluation of carcinogenic risks to humans, Lyon, v.88, p. 39-325, 2004.

IWAKIRI, S. Painéis de Madeira reconstituída. Curitiba: FUPEF, 2005. 245 p.

IWAKIRI, S.; KEINERT JÚNIOR, S.; PRATA, J. G.; ROSSO, S. Produção de painel compensado estrutural de Eucalyptus grandis e Eucalyptus dunnii. Floresta, Curitiba, v. 37, n. 3, p. 363-367, 2007.

IWAKIRI S.; OLANDOSKI, D. P.; LEONHARDT, G.; BRAND, M. A. Produção de chapas de madeira compensada de cinco espécies de Pinus tropicais. Ciência Florestal, Santa Maria, v. 11, n. 2, p. 71-77, 2001.

KABOORANI, A.; RIEDL, B.; BLANCHET, P.; FELLIN, M.; HOSSEINAEI, O.; WANG, S. Nanocrystalline cellulose (NCC): a renewable nano-material for polyvinyl acetate (PVA) adhesive. European Polymer Journal, Québec, v. 48, n. 11, 2012.

MENDES, R. F., BORTOLETTO JÚNIOR, G., VIDAL. J. M., ALMEIDA, N. F., JANKOWSKY, I. P. Efeito do tratamento preservativo de painéis compensados sobre as suas propriedades físico-mecânicas. Scientia Forestalis, Piracicaba, v.41, n.100, p.507-513, 2013.

MÖLLEKEN, R. E.; TRIANOSKI, R.; CLARO NETO, S.; PEREIRA, C. R.; IWAKIRI, S.; AZEVEDO, E. C. Evaluation of pressing time in the production of edge glued panel with adhesive polyurethane derived from castor oil. Applied Adhesion Science, v. 4, p. 9, 2016.

NGARGUEUDEDJIM, K.; ANNOUAR, D. M. Anisotropic behavior of natural wood palmyra (Borassusa ethiopum Mart) of chad. International Journal of Mechanical Engineering and Technology, v. 6, n. 9, p. 102-111, 2015

ÖZTÜRK H., DEMIR A., ÇOLAK S., Some mechanical properties of plywood produced using with polyethylene as adhesive from different wood species. Journal of Forestry Faculty, v. 17, n. 3, p. 458-463, 2017 
PEREIRA C. R.; MÖLLEKEN, R. E.; SOUZA, F. H.; CAPELLARI, G. S.; CLARO NETO, S.; AZEVEDO, E. C. Evolution of MDF bonding with polyurethane of castor oil. Applied Adhesion Science, v. 4, p. 13, 2016.

REZENDE, M. A.; ARONI, A. S.; COSTA, V. E.; SEVERO, E. T. D.; LATORRACA, J. V. F. Densidade e produtividade da madeira de híbrido e seminal de Pinus caribaea. Floresta e Ambiente, Seropédica, v. 15, n. 2, p. 8-17, 2008.

ROSA T. S. Utilização de cinco espécies de Eucalyptus provenientes de plantios de curta rotação para a produção de painéis particulados. 113 p. 2015. Dissertation (Masters in Forestry) - Universidade Federal do Paraná, Curitiba, 2015.

SALTHAMMER, T.; MENTESE, S.; MARUTZKY, R. Formaldehyde in the Indoor Environment. Chemical reviews, v. 110, n. 4 , p. $2536-2572,2010$.

SILVA, G. C. Qualidade de painéis aglomerados produzidos com adesivos à base de lignosulfonato e uréia-formaldeído. 2015. Thesis (PhD in Forestry Science) - Universidade Federal Rural do Rio de Janeiro, Seropédica, 2015.

SOLAL C., BOULANGER G., ROUSSELLE C., MANDIN C., DOR F., CABANES P. A..Evaluation des risques sanitaires pour La population générale liés à La présence de formaldéhyde dans lês environnements intérieurs et extérieurs. Air Pur. n. 74, 2008.

TRIANOSKI, R.; IWAKIRI, S. Pure and decorative plywood panels from Cordia trichotoma and Grevillea robusta. Floresta e Ambiente, Seropédica, v. 25, n.3, 2018. 